\title{
Nikolay Punin and Russian Futurism
}

The avant-garde movement in the arts that became Futurism took shape between 1908 and 1913, first in Italy and then in Russia, achieving international prominence, even notoriety, and its greatest influence in the years immediately following the First World War. Closely related to Vorticism in England, Cubism in France, and some aspects of German Expressionism, in tone Futurism was antitraditional, anticanonical, and extremely antibourgeois. There was some affinity with radical political movements, with the new government in Russia, and with fascism in Italy, although it would be a mistake to characterize Futurism as either bolshevik or fascist. In the long run these (always tenuous) political associations served Futurism most unhappily.

Nikolay Nikolaevich Punin (1888-1953), art historian and critic, was probably the most respected voice of Russian Futurism in the visual arts. As a critic he was as important to the painting and sculpture of his time as the better-known Formalists were to literature. His lifetime spanned the old regime, all three twentieth-century Russian revolutions, the scrambled world of the New Economic Policy (NEP), and the Stalin years. A talented writer deeply involved in a dynamic cultural milieu, Punin brings that world and its inhabitants to life in his diaries.

In spite of the current "postmodernist" groundswell against the "modernist" hegemony over the arts of the I920's, we are becoming increasingly aware of the expressive greatness, the variety, the innovativeness of those anni mirabiles, as well as the many follies, above all their arrogant tendency to overreach and outdo themselves. We have discovered new virtues in previously "rejected" writers like Wyndham Lewis, Blaise Cendrars, Djuna Barnes, Andrey Platonov, and Marina Tsvetaeva* as well as half-accepted painters like James Ensor and René Magritte and deepened our understanding of the "giants"-James Joyce, T. S. Eliot, Ezra Pound, Osip Mandelshtam, ${ }^{*}$ Boris Pasternak, Anna Akhmatova, Pablo Picasso, Wassily Kandinsky, Kazimir Malevich*_ I make no attempt to name them all; they are numerous. What seems to be going on in postmodernism is a rejection in the arts of what some call the megalomaniacal or "totalitarian" aspects of the putative modernist aspiration to change the world or make the whole world into a work of art and at the same time a scholarly-critical appreciation of the vitality, energy, originality, variety, cosmopolitanism, and revolutionary 
spirit of the intensely intercommunicative arts of the 1920's and continued exploratory use of many of the artistic devices they pioneered. ${ }^{1}$

Among these arts, self-styled Futurism had a distinctive place. It emerged in the visual arts out of its predecessor, Cubism, and involved both a continuing abstraction of forms and a hypostatization of the machine. To the Futurists all life either resembled a machine in its power and efficiency or fairly cried out to be refashioned in that mode. Ironically perhaps, the movement arose in the two least industrialized and least mechanized countries of Europe-Italy and Russia. Perhaps, as some writers have suggested, this was because Italy and Russia, still at an early stage of industrialization, could regard the modern city as a place of hope and the machine as a kind of savior. ${ }^{2}$ Perhaps it was merely a reaction against the prevailing artistic language in the process of degenerating into sentimentality and vagueness, grown stale and remote from daily usage.

There was much about Futurism that was transient and ephemeral: its strident tone was bound to grow hoarse, its cocksureness to falter, its contempt for tradition and convention to be seen as a figleaf disguising the insecurity of raw ambition. Nevertheless, it was a movement that changed artistic practice and understanding forever. Nikolay Punin was quick to grasp its vitality and its relevance to modernity. He became its most eloquent spokesman and most persuasive critic.

Yet he was never "merely" a Futurist critic. Like all great critics, he was too sensitive, too intelligent, too erudite to be the man of one school only. His deeper commitments were to art and the expansion of human horizons. Many contemporary artists whom he was the first to appreciate were far removed from Futurism. He was a pioneer in the renaissance of interest in the old Russian icon. He thought the realist nineteenth-century Russian school of art known as the Wanderers* (Peredvizhniki) underappreciated. He brought Japanese and Oriental art into the Russian art scene. He was a formidable scholar of the European art of the Renaissance.

Turn-of-the-century Symbolists, whose modes dominated the arts and at whom the Futurists took aim, tended to link poetry and music, but the Futurists saw the most vital connection as between poetry and the visual arts. Throughout the nineteenth century there had been an intensive exploration of the relationship among the arts and a symbiosis among them. Friedrich Nietzsche's Birth of Tragedy from the Spirit of Music had an enormous impact on the Symbolists, as did Richard Wagner's concept of the Gesamtkunstwerk.

The Futurists by no means abandoned the link to music or the search for a "total" work of art, but they derived their fundamental inspiration from Paul Cézanne's reordering of space and spatial forms, 
as well as from the latest philosophical and scientific theories of the relationship between space and time. ${ }^{3}$ The Cubist tendency to include bits of the real world in artworks - newspaper clippings, bits of objects, etc. (collage) - continued into Futurism and beyond into its offshoots in Russia, such as Constructivism. Constructivism (and its prime mover, Vladimir Tatlin)* tended more and more to smear the boundary between life and art, to take art out of the "musey-rooms" and into the streets, to abolish the necessity of "the esthetic gaze," and to create instead the art of "materiality," to make life into art, while the Suprematists (Malevich here) sought to refocus the esthetic gaze on primordial forms, primitive perceptions of shape, color, and texture. ${ }^{4}$

Futurist poets, who were generally also painters, tried to develop what they called a "metalogical" language (zaum)* that transcended ordinary sense and made full use of the expressive qualities of the sound and rhythms of language, the deep inner impulse of words to dance. Vladimir Mayakovsky, ${ }^{*}$ Velemir Khlebnikov, ${ }^{*}$ and Aleksey Kruchenykh also paid minute and meticulous attention to how words looked on the page, to the art of the book. Sound, sight, and sense were intricately interwoven. $^{5}$

Russian Futurists were prolific with manifestos. Indeed, they turned the manifesto into an art form, using typographical devices, distortions of conventional line-spacing, capital letters, different typefaces, especially italics, drawings - many of the eye-catching devices that nineteenth-century radical pamphleteering had pioneered to catch the eye of newly and crudely literate readers. They used street-theater and performance art to attract attention, bizarre costumes to distinguish themselves from the more genteel Symbolists. The Futurists were outsiders, as against the established canonical artists and styles. They were hooligans who felt a natural sympathy with radical revolutionary political movements, but were not reliable members of underground organizations. Leon Trotsky saw them as bohemians making a bid for public notice with their bizarrerie. ${ }^{6}$ Lenin (Vladimir Ulyanov) viewed them with puzzled distaste. At the revolutionary moment, however, the bolsheviks accepted whatever intelligentsia support they could get, whether from the wild Futurists or from a great, weary Symbolist like Aleksandr Blok.*

As a movement in the arts and as an artistic language Symbolism had no doubt grown tired. In a 1922 essay the poet Osip Mandelshtam wrote:

The Russian Symbolists discovered . . the primal figurative nature of the word. They put a seal on all words, all images, designating them exclusively for liturgical use. This has very uncom- 

sible to light a fire, because it might signify something that would make you unbappy.

Man was no longer master in his own house; it would turn out he was living in a church or in a sacred druidic grove. Man's domestic eye had no place to relax, nothing on which to rest. All utensils were in revolt. The broom asked holiday, the cooking pot no longer wanted to cook but demanded for itself an absolute significance (as if cooking were not an absolute significance). They had driven the master from his home and he no longer dared to enter there. ${ }^{7}$

One thinks of Gertrude Stein and "A rose is a rose is a rose."

Nevertheless, Mandelshtam also and rightly characterized the Symbolist movement as leonine. Both Futurist and Acmeist practice were dependent on it, like the biblical honeycomb in the dead lion. ${ }^{8}$ One could argue that Symbolism, in spite of its respect for the past and the canon, was the first avant-garde movement in Russia. It is on the border of modernism, though which side of the border might be disputed. ${ }^{9}$ It is fair to say that Futurism derived as much from Symbolism as from Cubism, but this is a historical nicety, removed from the clatter and brouhaha of artistic conflict.

In any case no Russian poet or artist of the period between 1900 and I925 would have agreed with W. H. Auden's dictum that "poetry makes nothing happen." Auden was of course reacting against the Romantic notion of poets as "unacknowledged legislators" and the social pressures of the I930's and 1940's pushing poetry in the direction of social commitment. There was, however, a kind of "Futurist Moment" between I9I3 and 1923, in which it appeared to many that poetry might make almost anything happen, a sense that enormous changes were imminent and that the right word needed only to be said for them to happen. ${ }^{10}$

That was certainly the atmosphere of the avant-garde in the arts everywhere across Europe, whether it called itself Futurist, Vorticist, Surrealist, Expressionist, Dadaist, Absurdist, or whatever. Most of these movements began well before the First World War, but the war no doubt intensified and complicated matters. It gave a ferocious impetus to both the creative and destructive aspects of the avant-garde, introduced a heightened cynicism, and increased contempt for sentimentality, hypocrisy, and untruthfulness. A stalemated war of attrition helped polish the metaphor of an "avant-garde" with its implied daring, resourcefulness, and mobility. While it contributed to the awe over the power of the machine, it cast a shadow of doubt over the machine's 
presumed benevolence. Traditional authority was discredited, and not only in the arts. In Russia, a revolutionary government came to power and, as it withstood the assaults of traditional authority upon it, attracted to itself avant-gardist sympathies in general.

The attraction of a new world rising on the ruins of a discredited tradition (Ezra Pound's "old bitch gone in the teeth") was a powerful one. Few artists indeed had had much to do with the bolsheviks in Russia before the revolution, and the Russian intelligentsia as a whole refused to cooperate with them in their first months of power. But the bolsheviks dangled that tempting opportunity called "a new world" before the eager intellectuals. Nikolay Gumilev, ${ }^{*}$ a talented poet and even more talented critic and impresario, had always been a convinced monarchist and hated the bolsheviks, who shot him in a trumped-up treason case in 1921. But in 1919 and 1920 he ran a workshop for aspiring proletarian poets. ${ }^{11}$

Even traditionalists or retrospectivists like Gumilev or Anna Akhmatova were antibourgeois; it was part of the intellectual mind-set of the time, and not only in Russia. While Futurists wanted to throw the canon and its icons like Aleksandr Pushkin or Dante Alighieri "overboard from the ship of modernity"-i.e., refused to regard them as any longer canonic - the Acmeists and others more retrospectively inclined wanted to "make it new" (Pound's phrase again), insisting that tradition to remain alive had constantly to be renewed - a position not unlike T. S. Eliot's in his essay "Tradition and the Individual Talent." It is a mistake to exclude retrospectivists like Mandelshtam and Akhmatova and Eliot from the avant-garde.

The Russian Futurists, it is true, were mightily obsessed with the machine, in both the literary and visual arts. This made a gritty paradox: on the one hand, maximum impact on the audience, ambition to change the world; on the other, depersonalization, withdrawal from any interest in the nuance and detail of individual psychology, abandonment of both the individualized subject and the claim of the artist to hieratic mediation; on the one hand, a passionate charge of lyrical hyperbole, on the other, a condescension, a literal down-putting of merely personal emotion or precedence of lyrical feeling, whether of subject or artist. Nikolay Punin lived at the heart of this Futurist paradox.

Punin identified himself with the Futurist rejection of sentimentality, of obsession with the nuances of individual psychology (à la Anton Chekhov), of Symbolist mysticism and overemphasis on mood and tone, and of Symbolist neo-romantic hostility to intellection as stifling of passion and spontaneity. And yet he did not wish to lose his soul. $\mathrm{He}$ 
was aware of a certain conflict between mechanical abstraction and the spontaneity of feeling that was characteristically human, that he sometimes feared as deficient within himself, and that he struggled to retain.

Punin's career might well be called meteoric. By 1913, in his late twenties, he was a prominent figure in the Russian art world. By the 1920's, he was known abroad. After 1923, he began to encounter obstacles and his activities were restricted. From 1929 to 1949, he was known largely as a university teacher and the author of the standard textbook on the history of West European art. By the time of his final imprisonment in 1949, he was largely forgotten, both at home and abroad.

Until recently, Punin was almost unknown abroad except as a name attached to better-known figures, especially to Anna Akhmatova. And even his importance in her life and work has been grossly underestimated. ${ }^{12}$ During the heyday of his career, he championed artists like Vladimir Tatlin and Kazimir Malevich. The range and depth of Punin's artistic taste and knowledge were truly great and enabled him to recognize, appreciate, and articulate diverse talents, from the fierce expressionism of Vasily Chekrygin* to the restrained impressionism of Nikolay Tyrsa* and the more conservative style of Vladimir Favorsky, ${ }^{*}$ yet for all this he was but dimly appreciated.

At home, his memory fared only slightly better than it did abroad. In 1949, an enemy of his discovered indignantly that one of his books was still in print, and that was quickly remedied. A long generation after his death, in 1976, a book of his more conventional and conservative essays was republished with articles on icon-painting, various nineteenth-century Russian painters, Japanese art, and Picasso. ${ }^{13}$ Only in the last three years have some of Punin's most characteristic essays on the revolutionary art of the I920's begun to appear, largely through the work of his daughter, Irina Nikolaevna Punina, and members of her family. ${ }^{14}$ From among these we include in the present volume a fragment, "Apartment No. Five," as edited by Leonid Zykov. The full text was published in Panorama iskusstv (Panorama of the Arts), volume I2, by the Sovetskii Khudozhnik press (Moscow, 1989). For reasons of space it cannot be included here, but it is certainly worthy of translation as a whole. In 1930, Punin was commissioned by the State Publishing House (Gosizdat) to write his memoirs. Between 1930 and 1932, he wrote a work in twelve chapters, about two hundred typed pages describing the situation of the arts and cultural politics from 1916 to May 1917. The publishers rejected what he had written, no doubt for political reasons. We do not know whether Punin intended to continue or whether he considered it done. This was the book to be called Art 
xvii

NIKOLAY

PUNIN AND

RUSSIAN

FUTURISM

and Revolution. Zykov informs me that he and Irina Nikolaevna plan to publish it in Russian soon. From about 1916 until his death, Punin was arguably one of the three or four most talented art critics and historians writing in Russian. During the I920's, he was undoubtedly the most influential.

Anatoly Lunacharsky, ${ }^{*}$ Lenin's commissar of education (or enlightenment), appointed Punin head of the Petrograd regional visual arts section of the commissariat in 1919. The section was abolished in 1921; that was his only job within a government structure. His prestige and influence and importance did not depend on any official government appointment. His work in organizing the Petrograd museums, his teaching at the university, and his job on the board of the State Porcelain Factory, ${ }^{*}$ though prestigious and not without government connections, came to him on the basis of his professional merits. He was certainly no apparatchik, and not by character a commissar. As an editor of Iskusstvo kommuny (Art of the Commune) he was an important voice of Futurism and the avant-garde. He was the only self-proclaimed Futurist who had anything like an ecumenical education in art history.

Far from a powerful egotist, Punin was a man constantly torn by self-doubt, frequently troubled and even self-denigrating. He deeply envied Akhmatova her poetic creativity, but envy (so destructive in some lovers) drove him not to attempt to destroy her, but to love, cherish, and even depend on her. Above all, he was torn by the Futurist paradox, the struggle between deeply charged personal emotion on the one hand and the ideal of intellectual control and aggressive mechanomorphic abstraction on the other. He tried to combine the words "thought" (mysl') and "feeling" (chuvstvo) into a hyphenated thoughtfeeling or feeling-thought, but what T. S. Eliot called the "dissociation of sensibility" in literature, the reciprocal distancing of thought from feeling that Eliot considered so debilitating, Punin never entirely escaped.

At this point I should say something about how the diaries came to Austin. The story, which has its own pleasures, also bears on the larger picture.

While living in Leningrad in 1974 , researching a book on the cultural significance of St. Petersburg, I became acquainted with the city's literary "semiunderground." It was the time of Leonid Brezhnev; Stalinist terror was a thing of the past, but life was far from comfortable for writers and artists whose works did not conform to the crumbling but still enforced standards of Socialist Realism. Brushes with the KGB, arrests, and threats of arrest were common. It was the time of Aleksandr Solzhenitsyn's expulsion from the Soviet Union. Publication and exhi- 

"known," to have a "public," was denied them, except on official conditions that most refused to accept.

It was the time of clandestine poetry readings and art exhibits in private apartments. "Art" had become a way of life and gathered to itself an extraordinary array of vivid, intense, dedicated personalities. Some were talented, some not very; and the narcissism of these occasions did not altogether pass me by, though as long as a sinister knock on the door followed by arrests and confiscations remained a real possibility, these gatherings had their charm and excitement. This was the world of Andrey Sinyavsky, under his pseudonym Avram Tertz, described so vividly in his story "Graphomaniacs." In this world, Futurism, while not the only presence, was a powerful one. But it was a Futurism curiously detached from conscious politics, a purely "art for art's sake" Futurism!

Most of those who attended knew each other, read each other's works, and commented at length with free and easy spontaneity on each other's pictures. They all claimed to be fed up with any kind of politics, for or against the regime. Of course, that was in itself a political stance, and all knew it would so be regarded by the authorities.

In this milieu I became acquainted with Konstantin Kuzminsky, a figure of notorious eccentricity. In his early thirties at the time, he had a full beard, a paunch, red hair, blue eyes a little dimmed by drink; dressed in old leather; and was easily engaged, with a disposition toward extreme statement and a striking appearance that called to mind the anarchist Mikhail Bakunin or a number of Russian saints. Kuzminsky was a Leningrad poet of the same generation as Joseph Brodsky. He had run afoul of the regime, had refused to give way to it, and continued to act in a flamboyant, nonconforming manner. ${ }^{15}$

Kuzminsky had a flair for public drama. One morning, for example, he stretched himself full-length on Nevsky Prospect, the busiest street in Leningrad, forcing traffic to move around him. (To this very day I regard his confidence that traffic would move around him as a remarkable act of faith, worthy of his resemblance to the saints!) His own writing dwindled. He enjoyed reading passages from his own and others' samples of zaum and the spluttering reaction of much more genteel members of an older generation who would accuse him of being, as he put it, "A Fu-fu-fu-fu-futurist!"

Kostya became an impresario of "unofficial" Leningrad poetry and painting. He compiled vast typewritten anthologies and attended innumerable exhibits. His father had been a well-known, conventional Socialist Realist painter, a member of the academy, but however 
strained relations might have been between Kuzminsky and the old man, Kostya did learn a thing or two about painting from his father. Talented painters respected his opinion of their work. He knew vast amounts of poetry by heart and would recite at great length. He also took a certain pleasure in discomfiting me by long quotations from English poets I had little taste for, like Rudyard Kipling and Algernon Charles Swinburne.

Kuzminsky militantly aligned himself and his own writing with the Futurism of the years 1908 to 1922, and with Cubo-Futurist painting, but as an impresario he remained refreshingly eclectic. Writers of all schools brought their works to him. He even pirated some. His aim was to collect all poetry that could not officially be published. Intellectuals, Russian and foreign, who spent any time in Leningrad gravitated toward Kuzminsky, putting him at the hub of what was, to be sure, a rather small universe. It was big enough, however, to prompt the regime to make life increasingly uncomfortable for him. He applied to emigrate, and the authorities let him go.

Kostya had important "connections," who worried about him, and everyone knew the first weeks in America were hard for an immigrant. Martha Golubeva, ${ }^{*}$ Punin's last wife (referred to in the diaries as "Tika"), had once been Kuzminsky's mother-in-law. Punin had entrusted most of his archive to his daughter, Irina Nikolaevna, but part, including the Punin-Akhmatova correspondence, to Golubeva, under the not unrealistic apprehension that if they came into Akhmatova's possession she might censor them. Golubeva died in 1963. After her death, her daughter, Nika Kazimirova, returned some, but not all of the archive to Irina Nikolaevna and her family (including Leonid Zykov). Nika was charmed by Kuzminsky and married him. By 1974, when I arrived on the scene, they were divorced; Kuzminsky had remarried and so had Nika, yet she retained considerable affection and concern for him. She offered to sell an important part of Punin's diary to my university for his benefit. A check was immediately forthcoming to ease Kostya's early days in expensive, hurly-burly America.

The most important result of Kuzminsky's first years in America was a massive anthology, in many volumes, of unofficial Russian poetry. ${ }^{16}$ It does not reflect the taste of his own writing, but a genial and generous eclecticism. It is rather Punin-like in this respect. It is dedicated to the ongoing life of poetry as such, not to Futurism.

The notion, much bruited about recently, that Russian Futurism as the heart of the avant-garde nourished rather than opposed the principles of Socialist Realism, while it may contain a grain of bitter truth, is fundamentally belied not only by the generous taste of the "too late" 

ance of Futurism's chief ideologue when it was in its prime, Nikolay Punin. ${ }^{17}$

Thanks to Irina Nikolaevna Punina and Leonid Zykov there has been a recent revival of interest in Punin. She has generously provided us with portions of her father's diary, letters, newspaper clippings, and other documents from his archive. In this volume we have included all of our original purchase (1915-1936), while editing, with current American interests in mind, the remainder. Konstantin Kuzminsky has, in the meantime, established himself in the United States and is now holding court in rural New York clad in his accustomed Oblomovian robe. He travels little (due largely to the American ban on smoking in airplanes), writes a column for the New York Russian newspaper Novoe Russkoe Slovo, and remains a Futurist. His multivolume anthology of unofficial Russian poetry of the 1960's and 1970's stands as a unique work, a monument for the perusals of scholar and prosodist, an exotic maze for the more casual Russian reader.

While Punin might well have been capable of echoing Emilio Marinetti's encomium to "la macchina," his more considered opinion would have been that the roaring car and the winged victory were both beautiful. ${ }^{18}$ ("The form is the same; the content changes . ..") Although his rhetoric was rather better, he might well have echoed Kazimir Malevich:

The new life of iron and the machine, the roar of motor cars, the brilliance of electric lights, the growling of propellers, have awakened the soul which was suffering in the catacombs of old reason and has now emerged at the intersection of the paths of heaven and earth. ${ }^{19}$

Punin's writings of the period were not immune to that exultant, apocalyptic, cosmic tone, but the diary on the whole strikes a rather different note, generally more moderate and more easily available to common human experience and sympathy.

In literature it is well known that Russian Formalist literary criticism arose as a defense of Russian Futurism. Its key concept, "defamiliarization" (ostranenie), "making it strange," or "making it new," justified the aggressive Futurist assault on generic boundaries. The expression of areas of human life and experience exhausted by the generic resources of conventionalized high art could be freshened by drawing on previ- 
ously despised or ignored genres or unexpected perspectives. This seemed to the Formalist critics a key to the process of literary history, which at the same time justified literary study as an autonomous discipline, relatively independent of social and political shifts. ${ }^{20}$ Although the Formalists had been influenced by two notable German theorists of art of the period between the turn of the century and 1914, Heinrich Wölfflin and Wilhelm Worringer, as had Punin himself, and although the Formalists were among the first to take a serious theoretical interest in the new art of the cinema, they contributed nothing directly to criticism of the other visual arts. ${ }^{21}$

Reasons for keeping a diary can be varied and complex. From 1934 to I953, merely writing a diary in the Soviet Union was a risky business. Punin himself razored out a number of pages. Nika Kazimirova razored out the entries for October 1917. Even after Punin's death in 1953 there was a risk attached to the diary, and the family showed courage in keeping it intact. The diary omits mention of Punin's meetings with many of the cultural luminaries of the period, so it is doubtful that its primary purpose was mnemonic. It was primarily an exploration of his own inner self, a dialogue with his soul, one might say, except that Punin had a certain distaste for such language. What is expressed in these pages is not a powerful ego or some megalomaniacal need to change the world, but a deep need to be in tune with the changes that are taking place, to be alive in his time. In spite of the fact that he takes pains to show the diary to a select few - to women only, as it turns out; Akhmatova particularly, with whom he even maintains a "conversation book" (the phrase is Zykov's), but also (select passages) to Galya, Tika, and Irina - it is fundamentally a private document. Self-doubt is one of its most prominent motifs. Yet I think that he wanted posterity to read it. At the same time, he allowed it to pass through the filter of the women who loved him the most. In part, he kept a diary to test the adequacy or inadequacy of words in relation to his thoughts and feelings, or "thought-feelings" as he put it; in other words, because he was a writer.

He begins the diary at the age of sixteen, writing in the somewhat stilted literary language he later attacks as having no relation to contemporary life. He searches his memory of the past ten years for "significant" events, one of the most vivid of which is the death of his mother, his reaction to it, and the interpretation laid on that reaction by other members of his large family. His siblings thought him cold and unfeeling. One cannot help thinking of the episode of the mother's death in Leo Tolstoy's early novel Childhood, and there is something of the flavor 

to distinguish between what one is supposed to feel on such occasions (and the temptation to act out what is expected of one) and the complex, dense obscurity of what one really feels.

Like other men who have lost a tender, loving mother in childhood, Punin always felt the powerful need for a woman's love and approval, and no single love, no single source of feminine affection, could ever be quite enough. He needed a woman who regarded him as central to her life. He could temporarily tolerate (with some pain) shared affection for "sibling" rivals, but the sense of his own centrality had constantly to be renewed. The diary notes two or three passionate love affairs and some minor infatuations. There is the Turgenev-like (First Love) unconsummated "triangle" with Lida Leonteva ("Dama Luni")* and the student Evgeny Fedorov. There is his wife, Galya Ahrens, ${ }^{*}$ who in the long run, he says, was the "only one" who remained loyal to him. There is the beautiful, dazzled young student $\mathrm{N}$. There is the notorious glamour-girl of the art-world of his time, Lilya Brik, ${ }^{*}$ who lived in a ménage-à-trois with her husband and the poet Vladimir Mayakovsky and whose sensual delights haunt Punin, along with her "impossible" opinions. There are two or three others. But above all there is his long, deep, unstable yet remarkably persistent involvement with Anna Akhmatova, one of the great poets of her time, a towering beauty in a world of small women. ${ }^{22}$ The diary makes clear that their relationship was deeper and had a far greater influence on both their lives than is commonly assumed.

Punin came from a large, warm, conservative, upper-middle-class family. His father was a doctor who had served in a military hospital in Helsinki where Nikolay, or Kolya, was born and later a prosperous practitioner in Pavlovsk and Tsarskoe Selo.* The doctor was traditionally religious and in Nikolay's earlier years a rather stern taskmaster, though more tolerant later. When Nikolay tried to shy away from what he feared would be a difficult Greek exam, featuring Plato, the old man insisted he take it; the later Platonist who repeated in his art criticism that "it is the content that changes; the form remains the same" fondly kept the old man's letter in the same notebook as his own diary. Both his mother and his stepmother were traditional Christians, and conventional religion was part of the family atmosphere. As an adolescent in touch with the ideologies of his time, Punin lost his Christian beliefs. Later, as a Futurist ideologue himself, he saw religion as part of that world of sentiment and feeling that the Futurists thought needed to be brought under the control of superior consciousness and precise knowl- 

machine. Yet he never entirely managed to repress what were undoubtedly religious needs. Instructively, he later noted in his diary: "The way to God is woman."

Punin was a precocious reader, and his notes on Immanuel Kant and Arthur Schopenhauer were quite sophisticated for his age. Later he discovered Nietzsche, with whom the diary continues a love-hate affair almost to the end. In general his comments on philosophers are acute and articulate but not markedly original, with one exception. Although he never had more than moments of enthusiasm for Marxism, a brief flirtation really, he did note that while Marxism was a weak philosophy, it nevertheless provided a credal system out of which a "real" philosophy "might grow."

From an early age, Punin admired Germany-indeed, he was an enthusiastic Germanophile and hated England. Germany was the heart of Europe, the most advanced country, homeland of philosophy, music, and the machine. And the homeland of socialism - especially of a kind of socialism that was as much aristocratic and monarchical as democratic; that was indeed somewhat resistant to democracy, about which young Punin, as a Nietzschean, had mixed feelings. Even with the outbreak of war, even with the death of his brother in the war and the overflow of youthful patriotic Russian emotion, he retained his admiration. Rather than turning anti-German, he continued to see Germany as the model Russia should emulate. In 1918, with his friend Evgeny Poletaev, ${ }^{*}$ he published a book called Against Civilization, fundamentally an attack on the Anglo-French liberal tradition and an encomium of Germany and German "state capitalism" that some have seen as "proto-fascist," though in the diary he expresses mixed feelings about the book.

Later, during the period of the Second World War and the terrible nine-hundred-day Siege of Leningrad, his admiration seems to have drained away, but a certain awe remained. In the early days of the siege, he refused evacuation to Samarkand (later he accepted), because that would have meant moving with the academy and he preferred solitude under siege, "chasing windmills," as he put it. His disillusionment with the regime was nearly complete by then, and he believed the bolsheviks, alas, would not seriously fight. In the streets, he noted the "sheepishly submissive faces of the passersby." He compared the atmosphere of the city under siege with that of the Ezhovshchina* in 1937, the most terrible year of the great purge. He took only casual note of the horrors like the severed hand lying in the snow after a German bombing. Yet 
on October II, 194I, he noted a change of atmosphere and mood in the city, a turn in the tide, the feeling that the city would survive the siege. He had long abandoned Germany as a touchstone.

In the early diary entries England served as Germany's antipode. In the 1920's, when Ramsey MacDonald's emergent Labor Party was having its ups and downs, in no small measure dependent on the British public's association of "socialism" with the newly created USSR, Punin's Anglophobia found nourishment in the daily newspapers. In 1925I926, and especially during the British General Strike, diplomatic relations between Britain and the USSR were very tense and were indeed for a time suspended. Punin was certainly not alone in England-bashing at the time of the forged so-called Zinovev Letter, but his call for war with Britain over the seizure of the Aland Islands dominating the Gulf of Finland was not widely echoed. ${ }^{23}$ It would be my conjecture that Akhmatova, who loved English literature and read it avidly, softened his attitude in later years.

Punin's dialogue with himself in the diary intensified and matured with the years. Although he noted at one point that "there is not a single contradiction in me," he made no attempt to fuzz over the many quite obvious contradictions that leap to the eye.

The Platonist who insisted that in art it was "the content that changes; the form remains the same" wrote with equal insistence that "beauty is not canonical." The cynic who called prostitutes "the only women brave enough to be sincere" boasted of Akhmatova's praise that "you can write like the tenderest of angels"; the "ladies' man" capable of carrying on three affairs simultaneously could also more or less sincerely reproach Akhmatova's infidelities: "It is characteristic of love that it relies on one person." The tender lover who called Akhmatova "Olen" (deer) and delighted in her nickname for him, "Kotik" (pussycat) or "Kotik Murr" (a cat story by E. T. A. Hoffmann), wrote on another page, "There is no wonder in my soul," and even denied that he had a soul at all. The realist who scoffed at superstition could not help seeing an earthquake that rocked Japan in the 1920's as a kind of cosmic revenge for the Russian defeat at Tsushima. The "spokesman" for Russian art who could in the early 1920's compare Picasso unfavorably with Tatlin could also write later, "Picasso is time, life itself." The Futurist, charmed by the power, efficiency, and beauty of machines, who could note, "I live like a well-organized machine," also resisted the encroachments of the cold steel of rationality upon the warmth of the human soul. "I have sworn not to become just a technical apparatus."

When Punin met Anatoly Lunacharsky for the first time in late November 1917, the new bolshevik commissar of education was socially 
isolated and ostracized and happy to greet any friend he could find from among the intelligentsia. ${ }^{24}$ Their temperaments were congenial. Lunacharsky, far from being a fanatic, had a certain reputation among the Party's core of being a political lightweight, indeed even frivolous. He called himself "an intellectual among the bolsheviks and a bolshevik among the intellectuals," which was a bit of a brag since he did not seem to have been very deeply committed either way. Punin knew that Lunacharsky was a poor critic and a terrible playwright, but they got along. Lunacharsky was a bon-viveur, expansive, generous, and amiable. He was sincerely enthusiastic about the arts and sciences and recognized the importance of maintaining their autonomy from political interference if their services to the ideals of the revolution were to be sustained. He appointed Punin as well as Punin's friend the avant-garde composer Arthur Lourie,* Malevich, and Tatlin and even Evgeny Poletaev to important positions in the commissariat. For some reason both Lenin and Nadezhda Krupskaya admired him; when Punin was arrested for the first time in I92I, for suspicions roused by his roots in the old regime, Lunacharsky came to his rescue. Unfortunately, when Punin was rearrested in 1936 and 1949, his old comrade was no longer among the living.

In his brief sketch "Apartment No. 5," Punin has captured some of the élan and enthusiasm engendered by that swashbuckling ex-sailor Vladimir Tatlin and early Constructivism. The dominant music here features the breakdown of boundaries between art and life, between the esthetic gaze and utilitarian reality, between the museum, the gallery, and the "musey-rooms" on the one hand and the streets, the boulevards, the squares, the factories, and the mills on the other. Tatlin was working on a model for his never-to-be-built monumental tower to the Third International. The conception was grandiose. It was to be of immense size, spiral in shape (the shape of revolution, Tatlin insisted), constantly in motion, containing offices, planning rooms, a landing pad, all twisting and turning, with an owl-like command of the entire cityscape. One knowledgeable and astute observer at least has compared Tatlin's conception of the tower to the Dome of the Rock in Jerusalem, which Tatlin must have seen in his sailoring days, the oldest surviving example of Moslem architecture, built in the days when Islam was a revolutionary, not a reactionary movement. ${ }^{25}$ Tatlin's disciples were assembling the model from a variety of materials and were talking passionately about the quality of materials, and Tatlin was urging them on with a barrage of curses, blessings, and (by no means a trivial item in the hungry days of War Communism, I918-192I) a pot of stew.

Before Tatlin, Punin was awestruck. He was a man of action, which 

clothes Tatlin designed for himself, to my eyes somewhat absurd, roused Punin's enthusiasm. Both Punin and Tatlin played an important role, however, in engaging accomplished artists to design clothes, as well as other items of mass consumption, for the people. Punin was on the managerial board of the porcelain factory that produced china designed by Futurist artists. ${ }^{26}$

While Punin as a critic defended both Tatlin and Kazimir Malevich, his deeper sympathies would seem to have been with Tatlin. For even the Suprematist Malevich, with his insistence on a return to primordial shapes, depended on the esthetic gaze to be seen as art. It was still "easel painting," whether the famous black square or the White on White, in which a white square painted on a background of a different shade of white melts imperceptibly at one of its nether edges into the background.

Tatlin, on the other hand, worked in the hubbub of daily life with the materials that daily life offered. He did not so much want to change the world as to bring out its true nature. In defending the design of his aircraft, the "Letatlin" (in Russian letat' means to fly) - a kind of oneperson glider - he insisted on its organic nature, learned, he said, from a close observation of birds and unlike the "mechanical" contraptions of aeronautical engineers. This might sound a bit strange from a Futurist worshiper of the machine; but one should remember the original meaning of "organic," derived from the Greek organon, meaning "tool" or "machine."

Recently, Boris Groys has argued that Stalinist Socialist Realism, far from being a negation of the esthetic dreams of the Russian avantgarde, was their fulfillment; that the dreams were megalomaniacal and totalitarian, whether to create a "new world" and a "new man" or to reveal a world and a man previously quite invisible and unknown. In spite of the radical discrepancy of styles, even in spite of what Stalinism did to the avant-gardists themselves or the systematic way in which it attempted to obliterate all evidence of modernism, there is a certain unhappy plausibility to this argument. ${ }^{27}$ And yet all great artistic vision has a touch of the grandiose and the megalomaniacal. Surely what is totalitarian is the means used to realize the vision, not the vision itself. An artistic vision requires artistic means, even when, as Tatlin attempted, it is carried out in the everyday world. Murder and prison are not among them.

A long-term debate within social-democratic Marxism, both in Russia and in Germany, has been summed up in the literature on the subject as one between consciousness (soznatel'nost') and spontaneity 

elemental"). These terms referred to the desired relationship between the organized social-democratic political parties and the working-class movements they were presumed to represent. ${ }^{28}$ All participants in the debate assumed the necessary existence of both elements; what was in question was the relationship between professional revolutionaries (fulltime intellectuals) and mass movements. Those who favored consciousness (like Lenin and Karl Kautsky) maintained that revolutionary change could not come about by means of spontaneity alone. The complexity and sheer massiveness of the modern world required study and understanding, which only full-time, professional revolutionaries could provide. The elemental movement had to be led by those who represented consciousness. Those who favored spontaneity (like Pavel Akselrod) saw the role of intellectuals and professional revolutionaries as providing clarity to issues that concerned the proletariat - clarification, elucidation, articulation, perhaps consular guidance-but no more than a shaping and articulating of what was primarily a movement of mass desires. One can see that this conceived relationship between consciousness and spontaneity was itself a bit abstract, quite complex, and could easily shift, depending on contingent circumstances and opportunities. In the long run, however, a Marxist revolutionary tended to belong to one side or the other of this debate.

One has to make only a slight transposition into individualpsychological terms (Freudian, if you will) to see the unconscious and the pleasure-principle as spontaneity and the ego and the realityprinciple as consciousness, to see the close analogy with what I have called "the Futurist paradox" and the long-term conflict that warred within Punin's psyche. His attraction to the feminine, his need for women's approval, his general association of the feminine and the emotional with inspiration and creativity, his awe before Akhmatova's creativity, his feeling of inferiority confronting it, his longing for "wholeness," and his growing discontent with the mechanical and the abstract tend on the whole to put him on the side of spontaneity. About his diary, he noted: "I am more human here than I am in my daily life, my essays, or my speeches."

Punin's powers as a writer were considerable. His description of the Leningrad flood of 1924 is unforgettable. He captures eloquently both the destructive force of the flood and the exhilaration with which an elemental event could enliven an otherwise flaccid and indifferent human community. Although he does not explicitly state the ironical resonance the flood had in the context of the city's history, he does communicate something of his historical awareness: two previous great 

caught pneumonia and died; in the second, his statue, according to Pushkin's "Bronze Horseman," withstood the elements and crushed the aspirations of the ordinary person. Punin's ironical wit also records what people were saying about the flood: some "blame it on the old regime"; others remark cynically, "Why are you all so happy about the flooding? It won't wash away the bolsheviks." It occurred in the year of Lenin's death, the year the city took his name.

Punin's description of the convent (monastyr'v Borisovke) where he spends a vacation with his family is full of sympathy for the archaic lyricism of the nuns' life and their bleak submission to circumstance and persecution. With the years, his antipathy for the bolsheviks and their rule becomes increasingly clear; yet his human sympathies at times include even them. One of his most unexpected insights occurs in the unlikely context of a badly conducted church service: it doesn't matter that the priest stumbles and cannot conduct the service properly; his congregation needs the words, even if they are not well spoken; similarly, he notes, even the incompetent communist agitator serves a certain popular need.

As the years pass, Punin's prevailing mood becomes more somber. During the war, in Samarkand, he thinks of the beauty of Leningrad in the spring. From time to time, a death-wish descends upon him. The storm and intimacy of his relations with Akhmatova are dispersed, yet some love and regard for each other remain to his death, and, for Akhmatova, well beyond.

Sculpture was not traditionally a Russian art; it was banned by the church. There were few Russian sculptors of the first rank before the latter part of the nineteenth century. When Lenin tried to mobilize extant talent to commemorate with fitting monuments historic Russian revolutionaries of all shades, the results proved meager and unsatisfactory. Revolutionaries do have their monuments in some places. But critics? Who has ever heard of a monument to a literary or an art critic?

Punin would not look well in bronze or marble. In words, however, he has his monument: a handful of essays, these diaries, the poems of Anna Akhmatova.

\section{NOTES}

Items followed by an asterisk can be found in the Glossary. antipodes, few tend to see the latter as a complete rejection of the former; on the contrary, most see it as a softened, more tolerant, less "purist," less "elitist" extension. See, for example, Hal Foster, ed., The Anti-Aesthetic: Essays on Postmodern Culture (Port 
$x x i x$

NIKOLAY

PUNIN AND

RUSSIAN

FUTURISM
Townsend, Wash.: Bay Press, 1983); and especially Charles Jencks, The Language of Postmodern Architecture, sth ed. (New York: Rizzoli, 1997). A writer who tends to stress the continuity between the avant-garde modernism and postmodernism is Marjorie Perloff, The Futurist Moment: Avant-Garde, Avant Guerre, and the Language of Rupture (Chicago: University of Chicago Press, 1986). Like Renato Poggioli, Theory of the Avant-Garde (Cambridge, Mass.: Harvard University Press, 1968), she posits a "Futurist Moment," a historical setting in which avant-garde movements that call themselves by different names and may indeed have had different intentions at their origin tend to take on the characteristics of the most radical (and perhaps "garish") among them. For Perloff that "moment" is 1913, though in her discussions it might well be extended to 1913-1923. Of course, the mixed and perhaps too limited receptions of artists like Cendrars, Magritte, and Ensor were based on the limitations of public taste. Platonov and Tsvetaeva, on the other hand, faced the problem of censorship and political suppression.

See Perloff, The Futurist Moment, pp. 8I-II5; 64-65.

For Symbolist "New World creation," see Irina Paperno and Joan Delaney Grossman, eds., Creating Life: the Aesthetic Utopia of Russian Modernism (Stanford: Stanford University Press, 1994). For Wagner and the Gesamtkunstwerk, see Thomas Mann, "The Sufferings and Greatness of Richard Wagner," in Freud, Goethe, Wagner (New York: Knopf, I942), pp. IOI-2II; Wagner attempted "complete communication to all the senses of all that could be said," p. I20. No one doubts Cézanne's seminal role in the creation of Cubism, but the precise nature of that role has been highly controversial. See, for example, the difference between Albert Gleizes and Jean Metzinger, Du "Cubisme" (Paris: E. Figuière et cie, 1912), one of the early attempts to "popularize" Cubism, and Guillaume Apollinaire, Les peintres cubistes (Paris: E. Figuière et cie, 1913). No one doubts that Picasso and Georges Braque were outstanding Cubist painters who owed a great debt to Cézanne; but again, the exact nature of their relationship to Russian and Italian Futurism has called forth different opinions. At the turn of the twentieth century and for the next decade, quantum and relativity theory both had a considerable impact on the visual arts. See Linda Dalrymple Henderson, The Fourth Dimension and Non-Euclidean Geometry in Modern Art (Princeton: Princeton University Press, 1983). It should be noted, however, that the "new science" and its departures from the Newtonian tradition encouraged a number of mystical interpretations, some by scientists themselves, such as Sir James Jeans, others by mystics with some (sometimes formidable) scientific credentials, like Rudolph Steiner and P. D. Ouspensky, Tertium Organum: The Third Canon of Thought, a Key to the Enigmas of the World (New York: Knopf, 198I). Some of the Futurists absorbed the new science by way of its mystical interpreters and also by way of Russian Orthodox mystical traditions in which they were steeped. Among the Futurists, Mikhail Matyushin* was a composer as well as a painter and composed music for the startling 1913 Futurist opera Victory over the Sun.

Kazimir Malevich, Essays on Art, 2 vols. (Copenhagen: Borgen, 1968); Charlotte Douglas, Swans of Other Worlds (Ann Arbor: Ardis, 1980); The Avant-Garde Heritage (St. Petersburg: State Russian Museum, 1994); Kazimir Malevich (New York: H. N. Abrams, 1994); John Milner, Vladimir Tatlin and the Russian Avant-Garde (New Haven: Yale University Press, 1983); see also Vahan D. Barooshian, Russian Cubo-Futurism, I910-1930: A Study in Avantgardism (The Hague: Mouton, 1974); Stephanie Barron and Maurice Tuchman, The Avant-Garde in Russia, 1910-1930 (Cambridge, Mass.: MIT Press, 1980); John Bowlt and Olga Matich, eds., Laboratory of Dreams: The Russian Avant-Garde and Cultural Experiment (Stanford: Stanford University Press, 1996); John Bowlt, The Silver Age: Russian Art of the Early Twentieth Century and the "World of Art" Group (Newtonville, Mass.: Oriental Research Partners, 1979), on "modern" but not avant-garde painters like Alexandre Benois, * E. Lanceray, etc.; John Bowlt, Russian Art of the Avant-Garde: Theory and Criticism, 1902-1934 (New York: Viking, 1976), which contains brief excerpts from Punin's criticism; Katerina Clark, Petersburg: Crucible of Cultural Revolution (Cambridge, Mass.: Harvard University Press, 1995); Peter Drews, Die Slawische Avantgarde und der 
$x x x$

SIDNEY

MONAS

Westen (Munich: W. Fink, 1983); George Gibian and T. W. Tjalsma, eds., Russian Modernism: Culture and the Avant-Garde, I900-I930 (Ithaca, N.Y.: Cornell University Press, 1976); Camilla Gray, The Russian Experiment in Art, 1863-1922 (London: Thames and Hudson, 1962); Anne d'Harnoncourt, ed., Futurism and the International Avant-Garde (Philadelphia: Philadelphia Museum of Art, 198I); Konstantin Kuzminskii et al., eds., Zabytii avangard: Rossiia, pervaia tret' XX-ogo stoletiia (Moscow, 1992); Vladimir Markov, Russian Futurism: A History (Berkeley: University of California Press, 1968); Nicoletta Misler and John Bowlt, Pavel Filonov: A Hero and His Fate (Austin: Silvergirl Press, 1983); Antony Parton, Mikhail Larionov and the Russian Avant-Garde (Princeton: Princeton University Press, 1993); Nikolai Punin, "Obzor novykh techenii v iskusstve v Peterburge," Russkoe iskusstvo I (1923): 19-24; Karl Schloegel, Jenseits der grossen Oktober: Das Laboratorium der moderne Petersburg (Berlin: Im Siedler Verlag, 1988); Richard Stites, Revolutionary Dreams: Utopian Vision and Experimental Life in the Russian Revolution (New York: Oxford University Press, 1989); Kirk Varnedoe and Adam Gopnik, High and Low: Modern Art and Popular Culture (New York: H. N. Abrams, 1990); William C. Wees, Vorticism and the English Avant-Garde (Toronto: University of Toronto Press, 1972) (the Vorticists were clearly Futurists of a kind, though they attacked their Italian cousins as well as Braque and Picasso); see also Peter Selz, German Expressionist Painting (Berkeley and Los Angeles: University of California Press, 1974).

For collections of Futurist manifestos: Vladimir Markov, ed Manifesty i programmy russkikh futuristov (Munich: Slawische Propyläen, 1967); Giovanni Lista, ed., Marinetti et le futurisme: Etudes, documents, iconographie réunis et presentés par G. Lista (Lausanne: L'Age d'Homme, 1977); Umbro Apollonio, ed., Futurist Manifestos (New York: Viking, 1973).

Edward J. Brown, Mayakovsky: A Poet in the Revolution (Princeton: Princeton University Press, 1980); L. Magarotto et al., eds., Zaumnyi futurizm i dadaizm v russkoi kul'ture (Bern: Peter Lang, 199I); Velemir Khlebnikov, Snake-Train: Poetry and Prose, ed. and trans. Gary Kern (Ann Arbor: Ardis, 1976), The King of Time, ed. Charlotte Douglas, trans. Paul Schmidt (Cambridge, Mass.: Harvard University Press, 1995), and Collected Works, vol. I, Letters and Theoretical Writings, ed. Charlotte Douglas, trans. Paul Schmidt (Cambridge, Mass.: Harvard University Press, 1987); G. Janacek, The Look of Russian Literature: Avant-Garde Visual Experiments, 1900-1930 (Princeton: Princeton University Press, 1984); Susan B. Compton, The World Backwards: Russian Futurist Books, 1912-1916 (London: British Museum Publications, 1978).

Leon Trotsky, Literature and Revolution (Ann Arbor: University of Michigan Press, 1971), p. 130.

Osip Mandelstam, Selected Essays, trans. Sidney Monas (Austin: University of Texas Press, 1977), p. 76.

"And behold, there was a swarm of bees and honey in the carcass of the lion," Judges I4: 8. The biblical reference is to the lion Samson kills on the way to choose his bride. On his return, he finds the honeycomb in the dead lion and shares it with his bride and parents. He then presents a coded version of the incident to his companions as a riddle: "Out of strength, sweetness" was the motif of a prescient essay by R. P. Blackmur, "The Lion and the Honeycomb" (republished later in a book of that title) in which he indicated how the decaying remains of the New Criticism nevertheless could serve as sustenance for a literary revival. See, for example, Bowlt, The Silver Age. This is the major theme of Perloff, The Futurist Moment.

For Gumilev and his "Poets' Workshop," see Sergei Makovskii, Na Parnase Serebrianogo Veka (Munich: Press of the Union of Russian Emigrants from the USSR, 1962), pp. 217222.

I2 See the essay in this volume by Jennifer Greene Krupala.

13 Nikolai Punin, Russkoe i sovetskoe iskusstvo (Moscow: Akademiia Nauk, 1976); recently some of his writings on Tatlin have been collected by his daughter, in $O$ Tatline (Moscow: 
$x x x i$

NIKOLAY

PUNIN AND

RUSSIAN

FUTURISM
Literaturno-Khudozh. Agentsvo "RA," 1994). A proceeding such as that launched against Punin automatically meant a prohibition on publication. The accused's books were confiscated from all public libraries. There was no written legislation on this, but people in "responsible" positions were well aware of the considerable risk of disregarding such prohibitions. Lists of prohibited books and authors were distributed periodically to all public libraries. "Book-extermination" as an aspect of Soviet censorship deserves more scholarly attention than it has received, as Leonid Zykov, the current editor of Punin's works in Russian, has pointed out to me. Picasso, of course, never submitted to the strictures of Socialist Realism. As a foreign communist and a great showpiece for Soviet propaganda, he enjoyed a certain limited license to make the artistic commissars uncomfortable. Punin, $O$ Tatline.

Suzanne Massie, The Living Mirror: Five Young Poets from Leningrad (New York: Doubleday, 1970). Avram Tertz (Andrei Siniavskii), Fantasticheskie povesti (New York: Interlanguage Associates, 1967); see also Tertz, On Socialist Realism (New York: Knopf, 1960). On p. 83, Tertz mentions Punin on Mayakovsky: "The most daring [critic] of all was N. Punin ... At that time he was connected with futurism; he is completely forgotten now. As early as 1918 he noted 'the marked classicism of Mayakovsky's verses.' ... He forecast that 'much as he would like to, Mayakovsky will never again rebel as impetuously as he did in the past."”

Konstantin Kuzminsky, ed., The Blue Lagoon Anthology of Contemporary Russian Verse, Antologiia noveishei russkoi poezii v Goluboi Lagune, 9 vols. (Newtonville, Mass.: Oriental Research Partners, n.d.).

spokesman. It is not quite right to call him an "ideologue." Leonid Zykov is of the opinion that Punin was more caught up by the temperament of the "Futurist Moment" than deeply and genuinely committed in his view of art as a Futurist. There is much in the diaries to confirm this view.

Perloff, The Futurist Moment, p. 89.

Quoted by Perloff, The Futurist Moment, p. 12.

See Victor Erlich, Russian Formalism, 3rd ed. (New Haven: Yale University Press, 198I). P. N. Medvedev, The Formal Method in Literary Scholarship (Baltimore: Johns Hopkins University Press, 1978; the Russian edition first appeared in Leningrad in 1928), is widely held to have been written by Mikhail Bakhtin; even those who deny his authorship see clearly the stamp of his influence. It is in this book that the charge is leveled. Relevant here, too, is the collection of Bakhtin's essays Speech Genres and Other Late Essays, trans. V. McGee (Austin: University of Texas Press, 1987); see the interesting commentary on these two works by Matthia Freise, Michail Bachtins philosophische Aesthetik der Literatur (Bern: Peter Lang, 1993).

The Complete Poems of Akhmatova are available in a bilingual (Russian-English) edition with useful annotation and supplementary commentary on the poet: Roberta Reeder, ed., The Complete Poems of Anna Akhmatova, trans. Judith Hemschemeyer, 2 vols. (Somerville, Mass.: Zephyr Press, 1990). There is a Public Broadcasting System documentary video on the poet narrated by Claire Bloom and Christopher Reeve, presented by WGBH, Boston, on November I8, 1991. See also the essay in this volume by Jennifer Greene Krupala. The most compelling source on Akhmatova's biography is Lydia Chukovskaya, ed., The Akhmatova Journals (New York: Farrar, Straus and Giroux, 1994), vol. I; four volumes have appeared in Russian; Zapiski ob Anne Akhmatovoi (Moscow: Kniga, 1989-1994); Amanda Haight, Anna Akhmatova: A Poetic Pilgrimage (New York: Oxford University Press, 1976); Roberta Reeder, Anna Akbmatova: Poet and Prophet (London: Allison and Busby, 1995). The much puzzled-over "guest from the future," a prominent figure in Akhmatova's Poem without a Hero, was almost undoubtedly Punin, as Zykov has pointed out in "Nikolai Punin-Adresat i geroi liriki Akhmatovoi," Zvezda I (1995): 77-103.

23 British troops were on the Aland Islands under the authority of the Council of the League of Nations. Russia had first occupied the islands in 1709 in the war against Swe- 
xxxii

SIDNEY

MONAS

den. According to the Treaty of Paris that settled the Crimean War in 1856 , the islands (which were less than fifty miles from Stockholm) were to remain unfortified. Imperial Russia administered the islands as part of the Grand Duchy of Finland. When Finland became independent in 1917, the international status of the islands was placed in doubt. However, the Alands Convention called by the League of Nations in I92I excluded Soviet Russia from its participants. War was out of the question at the time-Russia was in no shape to fight one. But the Soviet Foreign Office was understandably very unhappy. Punin makes note of the incident in 1925, because the Soviet Union used it as propaganda, claiming that England really wished to occupy and perhaps arm the islands in preparation for war against the Soviet Union. See the Pravda article "Angliia ukrepliaetsia na Baltiiskom more," August 2, 1925, and "Novaia ataka" in the August 9, 1925, edition of Izvestiia. The islands were awarded to Finland. In 1939, the Finns armed and refortified them, and Punin's fears were actually realized in the Russo-Finnish War. In the peace treaty that ended that war Finland was allowed to keep the islands, but unfortified and unarmed. Sheila Fitzpatrick, The Commissariat of Enlightenment (Cambridge: Cambridge University Press, 1970), pp. 114, I2I, where she calls Punin a "proto-fascist." Lunacharsky was the brother-in-law of Aleksandr Bogdanov, once a rival of Lenin's for preeminence in the bolshevik faction and the main object of Lenin's polemic against the "Godbuilders," in Materialism and Empirio-Criticism (New York: International Publishers, 1929). Robin Milner-Gulland, "Tower and Dome: Two Revolutionary Buildings," Slavic Review 47 (1988): 39-50. Lyubov Popova, ${ }^{*}$ Tatlin, and El Lissitsky were among the artists who designed plates and other china for the porcelain factory.

Boris Groys, Gesamtkunstwerk Stalin: Die gespaltenen Kultur in der Sowjetunion (Munich: Carl Hanser Verlag, 1988); translated into English as The Total Art of Stalinism: AvantGarde, Aesthetic Dictatorship and Beyond (Princeton: Princeton University Press, 1992); see also Groys' essay in Bowlt and Matich, Laboratory of Dreams.

The course of this argument in prerevolutionary Russia is most eloquently recounted in Leopold Haimson, The Russian Marxists and the Origins of Bolshevism (Cambridge, Mass.: Harvard University Press, 1955). 